\title{
Cognitive Avoidance Questionnaire: Factor structure and psychometric properties.
}

\author{
Jose M. Latorre ${ }^{1,2}$, Marta Nieto ${ }^{1,2}$, Laura $\operatorname{Ros}^{1,2}$, María A. Font ${ }^{3}$, Jesús Heras $\dagger^{1,2}$, and Jorge J. Ricarte ${ }^{1,2}$ \\ 1 University of Castilla-La Mancha. Department of Psychology, Albacete (Spain) \\ 2 Applied Cognitive Psychology Unit. University of Castilla-La Mancha (Spain) \\ 3 Unidad de Salud Mental, Hospital General de Villarrobledo, SESCAM, Albacete (Spain)
}

\begin{abstract}
Título: Cuestionario de Evitación Cognitiva: estructura factorial y propiedades psicométricas.

Resumen: La evitación cognitiva se refiere a las estrategias y esfuerzos dirigidos a prevenir experiencias negativas y eventos aversivos que provocan ansiedad. El presente estudio analizó la estructura factorial y las propiedades psicométricas de la versión española del Cuestionario de Evitación Cognitiva (CAQ; Sexton \& Dugas, 2008), un instrumento que evalúa cinco estrategias de evitación cognitiva relacionadas con la preocupación. La traducción al español se administró a una muestra no clínica de 614 participantes (18-82 años). La escala total y las subescalas mostraron una consistencia interna de buena a excelente. Utilizando el análisis factorial confirmatorio, se halló un modelo de segundo orden (i.e., cinco factores de primer orden y un factor de segundo orden) que mostró el mejor ajuste entre la estructura teórica y los datos empíricos. Se obtuvo evidencia de validez convergente y discriminante a través del análisis de las correlaciones del cuestionario con medidas de preocupación, supresión del pensamiento, rumiación y estilos de afrontamiento. Los resultados arrojaron datos preliminares satisfactorios sobre la adaptación española del CAQ que podría proporcionar mayores avances en la práctica clínica y la investigación sobre procesos cognitivos y trastornos de ansiedad.

Palabras clave: Cuestionario de Evitación Cognitiva; Trastornos de ansiedad; Preocupación; Estrategias de afrontamiento; Rumiación; Propiedades psicométricas.
\end{abstract}

\section{Introduction}

Avoidance, understood as the tendency to escape private internal experiences such as emotions, thoughts, and memories, is a natural reaction that is critical to individuals' survival (Hayes, Wilson, Gifford, Follette, \& Strosahl, 1996). However, this response may be maladaptive when excessive or unnecessary, being considered a risk factor for developing and maintaining emotional disorders, such as depressive and anxiety disorders (Barajas, Garra, \& Ros, 2017; Schäfer, Naumman, Holmes, Tuschen-Caffier, \& Samson, 2017; Struijs et al., 2018). In relation to such approaches, since the emergence of the "Third Wave" of therapies, much attention has been focused on the role of cognitive, behavioral and emotional avoidance in psychopathology (Eifert \& Forsyth, 2005; Hayes, 2016).

Cognitive avoidance entails a variety of strategies, such as distraction, worry, and thought suppression, aimed at avoiding or escaping thoughts about undesirable situations or problems (Sagui-Heson, 2017). Importantly, thought control strategies have been associated with anxiety disorders (Aldao, Nolen-Hoeksema, \& Schweizer, 2010; Goodwin, Yiend,

* Correspondence address [Dirección para correspondencia]

Dr. Marta Nieto López, Department of Psychology, Faculty of Medicine, University of Castilla La Mancha, Avenida de Almansa 14, 02006 Albacete (Spain). E-mail: Marta.Nieto@uclm.es

(Article received: 01-10-2019; revised: 04-11-2019; accepted: 11-02-2020)

\begin{abstract}
Cognitive avoidance refers to strategies and efforts toward prevention of aversive experiences and events that provoke anxiety. The present study analyzed the factor structure and psychometric properties of the Spanish version of the Cognitive Avoidance Questionnaire (CAQ; Sexton \& Dugas, 2008), an instrument which assesses five worry-related cognitive avoidance strategies. The Spanish translation was administered to a nonclinical sample of 614 participants (18-82 years). The total scale and subscales showed good to excellent internal consistency. Using confirmatory factor analysis, a second-order model (i.e., five first-order factors and one second-order factor) showed the best fit between the theoretical structure and the empirical data. Evidence of convergent and discriminant validity was obtained through analysis of the correlations of the questionnaire with measures of worry, thought suppression, rumination and coping styles. The results yielded satisfactory preliminary data on the Spanish adaptation of the CAQ, which could provide for further advances in clinical practice and research on cognitive processes and anxiety disorders.

Keywords: Cognitive Avoidance Questionnaire; Anxiety disorders; Worry; Coping strategies; Rumination; Psychometrics.
\end{abstract}

\& Hirsch, 2017; Servatius, 2016). Most of these disorders are characterized by worry, particularly in the case of generalized anxiety disorder (GAD; American Psychiatric Association, 2013; Hirsch, Perman, Hayes, Eagleson, \& Mathews, 2015). Worry has been defined as a chain of negative thoughts that are predominantly verbal and aimed at problem-solving (Borkovec, Robinson, Pruzinsky, \& DePree, 1983). The avoidance theory of worry and GAD considers worry, in part, to be a strategy for avoiding threatening images and the autonomic arousal they induce (Borkovec, Alcaine, \& Behar, 2004). In other words, individuals present excessive worry as a preparatory strategy in response to a threat, with the aim of averting the cognitive and physiological symptoms of anxiety (Behar et al. 2009). Consequently, cognitive avoidance has been considered a key process for both the prediction and maintenance of worry (Dickson, Ciesla, \& Reilly, 2012).

With further regard to the conceptualization of worry, the literature has suggested parallels with difficult to control repetitive thoughts concerning personal problems (i.e., rumination). Ruminative thought occurs in both normal individuals and clinical patients and is also a feature of anxiety disorders (Ricarte, Aizpurúa, Ros, Latorre, \& Raes, 2018). Worry and rumination may overlap between 16 and 21\% in both non-clinical and clinical samples (Segerstrom, Tsao, Alden, \& Craske, 2000). Moreover, they tend to be passive phenomena which interfere with problem-solving and are apt to aggravate anxiety (Matthews \& Wells, 2004). It has also been posited that both processes may be the paradoxical 
outcome of attempts at thought suppression (Dickson et al., 2012). With regard to the differences between the two processes, it has been suggested that worry is used to anticipate danger and prepare for action, while rumination is pastoriented (Capobianco, Morris, \& Wells, 2018). Rumination has been related to depressive disorders, although it may also be present in anxiety (Nolen-Hoeksema, 2000), while worry has been more exclusively associated with anxious symptoms (Behar et al. 2009). Hence, taking into account the relation between these strategies and cognitive avoidance and because of the implications for the understanding of emotional disorders (Hearn, Donovan, Spence, \& March, 2018; Newman, Llera, Erickson, Przeworski, \& Castonguay, 2013; Østefjells et al., 2017; Watkins \& Moulds, 2009), an instrument is needed to assess a wide range of cognitive avoidance strategies and related variables.

There exists a questionnaire of the above characteristics originally published in French under the title of Questionnaire d'evitement cognitif (QEC; Gosselin et al., 2002). The QEC measures cognitive avoidance using five sub-scales (Thought Suppression, Thought Substitution, Distraction, Avoidance of Threatening Stimuli, and the Transformation of Images into Thoughts). The first 41-item version was designed by a group of clinical researchers in 1996. The questionnaire was subsequently shortened to 25 items. In adult and adolescent populations, the results were fitted to a fivefactor structure, with good psychometric properties, criterion validity, and convergent and discriminant validity. Sexton and Dugas (2008) developed the adaptation and validation of the English version of the Cognitive Avoidance Questionnaire (CAQ), which demonstrated good to excellent internal consistency. Confirmatory factor analysis found support for the five-factor structure, despite the goodness of fit being lower than expected. Their version showed evidence of convergent validity related to measures of worry, thought suppression and coping styles. As a measure of discriminant validity, the scale was negatively correlated with informationseeking in controllable situations.

\section{The current study}

There is a need for an instrument in Spanish to assess cognitive avoidance as this would promote advances in clinical practice and subsequent studies on cognitive processes and mental disorders, especially GAD. In this sense, the importance of these types of transdiagnostic constructs is increasing, as functional avoidance is a widely used measure in different disciplines, but lacks specific, validated tests. Thus, and given that, to the best of our knowledge, there is no Spanish version of the CAQ, the aim of this work was to translate the questionnaire by Sexton and Dugas (2008) from English into Spanish, and analyze its psychometric properties in a non-clinical sample of Spanish participants. More specifically, the present study analyzed the factor structure of the CAQ using confirmatory factor analysis (CFA), examining its internal consistency and convergent and discriminant validity. In addition, we analyzed the contribution of the translated version in predicting worry after evaluating other variables of cognitive avoidance.

\section{Method}

\section{Participants}

The study sample comprised 614 Spanish Caucasian participants from a non-clinical population $(74.3 \%$ women; age range 18-82 years; $M=24.05, S D=11.84$ ), of whom 553 young adults were recruited from among university students (77.1\% women; age range $18-30$ years; $M=20.03, S D=$ 2.68); 57 middle-aged persons were recruited by means of public announcements (58.5\% women; age range 31-59 years; $M=45.89, S D=10.40$ ); and 24 older adults were recruited from active aging associations in different urban areas of the region of Castilla-La Mancha ( $45.8 \%$ women; age range $60-82$ years, $M=65.75, S D=5.72)$. All the participants were of middle-high socioeconomic status, with a mean yearly income of between 25,000 and 56,000 euros. The inclusion criteria were as follows: 1) being able to read and write; 2) for the group of older adults, presenting no signs of cognitive impairment at the time of assessment, as measured using the Spanish version of the Mini-Mental Status Examination ('Mini-Examen Cognoscitivo' [MEC], Lobo, Sanz, Marcos, \& Zaracemp, 2002); and 3) once informed of the study aims, agreeing to participate and giving signed informed consent. No participant was excluded from the study under these criteria.

\section{Measures}

\section{Cognitive Avoidance Questionnaire}

The CAQ is a 25-item self-report questionnaire that assesses the tendency to use cognitive avoidance as a strategy when dealing with threatening intrusive thoughts (Sexton \& Dugas, 2008). The scale has a five-factor structure: Factor 1 = Thought Suppression subscale (items 1, 2, 5 6, 14); Factor $2=$ Thought Substitution subscale (items 4, 11, 17, 20, 25); Factor 3 $=$ Distraction subscale (items 8, 10, 12, 13, 21); Factor $4=$ Avoidance of Threatening Stimuli subscale (items 7, 9, 16, 18, 22); and Factor $5=$ Transformation of Images into Thoughts subscale (items 3, 15, 19, 23, 24). Responses are scored on a 5point interval scale, ranging from $1=$ not at all typical to $5=$ completely typical. Higher scores indicate a greater tendency to cognitively avoid threatening internal events. The CAQ total exhibited excellent internal consistency $(a=.95)$. The five subscales showed internal consistencies as follows: Thought Suppression, $a=.86$; Thought Substitution, $a=.73$; Distraction, $a=.89$; Avoidance of Threatening Stimuli, $a=.87$; and Transformation of Images into Thoughts, $a=.87$. 


\section{White Bear Suppression Inventory}

The White Bear Suppression Inventory (WBSI; Wenger \& Zanakos, 1994) is a one-factor measure of the general tendency to suppress thoughts as a mental control strategy. It comprises 15 items scored on a 5-point Likert-type scale ranging from strongly disagree to strongly agree. The higher the score, the greater is the tendency to use thought suppression. The Spanish version of the questionnaire by González, Avero, Rovella, and Cubas (2008) identified a two-factor structure distinguishing between unwanted intrusive thoughts $(a=.87)$ and actions of distraction and thought suppression $(a=.80)$. Following the approach of Dugas, Gagnon, Ladouceur, and Freeston (1998), the present study uses only the thought suppression factor $(a=.86)$.

\section{Coping Response Inventory for Adults}

To evaluate coping strategies, we used the Spanish adaptation of the Coping Response Inventory for Adults (CRI-A; Moos, 1993) by Kirchneer and Forns (2010). The inventory has two parts. In the first part, the participant describes an important problem or stressful situation they have experienced in the last year, measuring the level of stress and the degree of perceived control, and responds to 10 questions that measure the participant's evaluation of the problem described. The second part comprises a 48-item self-report scale which assesses coping responses to stressful life experiences. The criteria are: no never; once or twice; quite often; yes, almost always. The scale identifies four approach strategies and four avoidance strategies. Approach strategies: 1) Logical analysis (LA): cognitive attempts to prepare mentally for a stressor and its consequences; 2) Positive reappraisal (PR): cognitive attempts to restructure a problem in a positive way while accepting the reality of the situation; 3) Seeking guidance and support (SGS): behavioral attempts to seek information, guidance, or support; 4) Problem solving (PS): behavioral attempts to take action to deal directly with the problem. Avoidance strategies: 5) Cognitive avoidance (CA): cognitive attempts to avoid realistically thinking about the problem; 6) Resigned acceptance (RA): cognitive attempts to react to the problem by accepting it; 7) Seeking alternative rewards (SAR): behavioral attempts to cope by finding substitute activities or creating new sources of satisfaction; and 8) Emotional discharge (DE): behavioral attempts to reduce tension by expressing negative feelings. The Spanish adaptation of the scale presents adequate psychometric properties and validity (Moos, 2010). The internal consistency of the Spanish version of CRI-A yields Cronbach's alpha values ranging from .50 to .70 for each of the subscales. In the present study, the cognitive avoidance subscale exhibited an internal consistency of $a=.63$.

\section{Short Depressive Rumination Scale}

The Short Depressive Rumination Scale (SDRS; Raes, Hermans, Williams, \& Eelen, 2007; Spanish adaptation by
Ricarte, Aizpurúa, Ros, Latorre, \& Raes, 2018) comprises four statements derived from the Leuven Adaptation of the Rumination on Sadness Scale (Raes, Hermans, Williams, Bijttebier, \& Eelen, 2007). Participants are asked to rate on a scale from 1 to 10 (never to very often) the frequency with which they do what is described in the four sentences when they are sad, down, or feel blue. Direct addition of all items is necessary to obtain the total score. The higher the score, the higher is the level of rumination. The Spanish adaptation by Ricarte et al. (2018) exhibited excellent internal consistency in its validation study $(a=.93)$ and in the present work ( $a$ $=.89$ ).

\section{The Penn State Worry Questionnaire}

The Penn State Worry Questionnaire (PSWQ; Meyer, Miller, Metzger, \& Brockovec, 1990; Spanish adaptation by Sandín, Chorot, Valiente, \& Lostao, 2009) measures the general tendency of an individual to worry, or trait worry. It comprises 16 items scored on a 5-point interval scale, ranging from 1 (not at all typical of me) to 5 (very typical of me). The Spanish version used showed good internal consistency and test-retest reliability. In the study sample, the PSWQ had an internal consistency of $a=.79$.

\section{Procedure}

Translation of the $C A Q$

Following the guidelines for translating psychological tests (Hambleton, 2005; International Test Commission, 2016), a preliminary forward English to Spanish translation of the scale was made by two of the native Spanish authors, who are completely bilingual and have experience in research on coping strategies and the adaptation of psychological assessment instruments. Subsequently, with special emphasis on the conceptual and cultural equivalence of the items, a qualified native English translator, familiarized with psychology but blind to the original scale, carried out a back translation. Lastly, to refine the instructions and all the items, the definitive version of the instrument was revised by bilingual translators, the authors of the present study and researchers from our department.

\section{Data collection}

Informed consent was obtained from all individual participants included in the study. The study data were collected in two phases. First, data were obtained from 147 participants to analyze the factor structure and psychometric properties of the Spanish adaptation of the CAQ, which, hereon in, we will call Cuestionario de Evitación Cognitiva (CEC). Second, we decided to increase the sample with the aim of achieving a better empirical fit of the data to the initially proposed theoretical model. A further 467 participants were then added to the measures of the CEC. That is, validity measures were not recorded for the increased sample. 
First, we held informational meetings with the management teams and the faculty officers of the collaborating organizations. Once permission to conduct the research had been received, data collection commenced. The data on the university students was collected in group format during class hours. The other assessments were administered in rooms at our university, individually or in groups, according to participant availability. Data collection was conducted in a single session. In the session, we explained the aims of the study, responded to any questions and collected the participants' informed consent before beginning the tests. It was made clear that the individuals invited to participate were doing so voluntarily and that they could answer the questions on the data collection form partially or completely and could leave the room at any time they wished. The data were collected by four examiners with experience in validating scales.

\section{Data analysis}

Data analysis was conducted using IBM SPSS Statistics 24.0 and AMOS-23 (Arbuckle, 2014). First, the normality of the data was verified, outliers were detected, and descriptive analyses were conducted. Second, CFA was used to evaluate the factor structure of the CEC and the internal consistency was verified by Cronbach's alpha coefficient. Third, the convergent validity of the questionnaire was assessed using Pearson's correlation analysis to examine the correlations between the CEC and the measures of worry (PSWQ), rumination (SDRS), thought suppression (WBSI) and cognitive avoidance (CRI-A). For the divergent validity, we analyzed the relation between the CEC and the two coping strategies from the CRI-A (logical analysis and positive reappraisal). Finally, hierarchical regression analysis was used to study the contribution of the CEC in predicting worry.

\section{Results}

\section{Preliminary analyses}

All the study variables were analyzed for multivariate outliers, univariate outliers, and normality of the distribution. A total of 26 multivariate outliers were identified using the robust Mahalanobis distance (Rousseeuw \& Leroy, 1987), and were eliminated from the dataset. For the univariate outliers, the typified scores were calculated. In accordance with the recommendations of Tabachnick and Fidell (2001), values falling 3.29 standard deviations $(p<.001$, two-tailed test) either above or below the mean were considered atypical. Following this criterion, no atypical univariate values were found. Finally, critical ratios for skewness and kurtosis were higher than 1.96, for both univariate and multivariate normality. Thus, the criterion of normal distribution was not fulfilled. Table 1 shows the descriptive analyses for the 25 items in the CEC and the corrected correlation coefficients between the items and the total questionnaire, whose values ranged between $r_{\text {corr }}=.39$ and $r_{\text {corr }}=.75$. Table 2 shows original items of the CAQ.

Table 1. Descriptive statistics and corrected item-total correlations of the CEC $(N=614)$.

\begin{tabular}{|c|c|c|c|}
\hline Item & $M$ & $S D$ & $r_{\text {corr }}$ \\
\hline 1 Hay cosas en las que preferiría no pensar. & 3.22 & 1.19 & .53 \\
\hline 2 Evito ciertas situaciones que me llevan a prestar atención a asuntos en los que no quiero pensar. & 2.77 & 1.08 & .62 \\
\hline 3 Sustituyo las imágenes mentales amenazadoras por cosas que me digo a mí mismo. & 2.47 & 1.14 & .45 \\
\hline 4 Pienso en cosas que tienen que ver conmigo como si le estuvieran ocurriendo a otro. & 1.91 & 1.07 & .40 \\
\hline 5 Tengo pensamientos que intento evitar. & 2.85 & 1.17 & .68 \\
\hline 6 Intento no pensar en los aspectos más molestos de algunas situaciones para así no tener demasiado miedo. & 2.56 & 1.13 & .63 \\
\hline 7 A veces evito ciertos objetos que me pueden provocar pensamientos molestos. & 2.15 & 1.14 & .64 \\
\hline 8 Me distraigo para evitar pensar en ciertos temas que me inquietan. & 2.79 & 1.15 & .67 \\
\hline 9 Evito a las personas que me hacen pensar en cosas en las que no quiero pensar. & 2.59 & 1.29 & .59 \\
\hline 10 A menudo hago cosas para así evitar mis pensamientos. & 2.51 & 1.14 & .67 \\
\hline 11 Pienso en detalles triviales para no tener que pensar en los asuntos importantes que me preocupan. & 2.03 & 0.98 & .61 \\
\hline 12 A veces me meto de lleno en una actividad para así no tener que pensar en ciertas cosas. & 2.73 & 1.16 & .63 \\
\hline 13 Para evitar pensar en temas que me perturban me obligo a pensar en otra cosa. & 2.56 & 1.11 & .70 \\
\hline 14 Hay cosas en las que intento no pensar. & 3.05 & 1.15 & .72 \\
\hline $\begin{array}{l}15 \text { Me repito a mí mismo cosas en la cabeza para no tener que visualizar los escenarios (una serie de imágenes } \\
\text { mentales) que me dan miedo. }\end{array}$ & 2.07 & 1.08 & .65 \\
\hline 16 A veces evito los lugares que me hacen pensar en cosas en las que preferiría no pensar. & 2.18 & 1.12 & .62 \\
\hline $\begin{array}{l}17 \text { Pienso en acontecimientos del pasado para no pensar en acontecimientos del futuro que me hacen sentir in- } \\
\text { seguro. }\end{array}$ & 1.83 & 1.08 & .49 \\
\hline 18 Evito las acciones que me recuerdan las cosas en las que no quiero pensar. & 2.27 & 1.05 & .75 \\
\hline $\begin{array}{l}19 \text { Cuando me vienen imágenes mentales que me molestan, me digo cosas mentalmente para sustituir a las imá- } \\
\text { genes. }\end{array}$ & 2.37 & 1.12 & .58 \\
\hline 20 Pienso en muchas cosas de poca importancia para así no tener que pensar en asuntos más importantes. & 1.88 & 0.96 & .55 \\
\hline 21 Hay veces que me mantengo ocupado solo para evitar que determinados pensamientos me vengan a la mente. & 2.51 & 1.16 & .69 \\
\hline 22 Evito las situaciones en las que tengo que tratar a personas que me hacen pensar en cosas desagradables. & 2.47 & 1.17 & .60 \\
\hline $\begin{array}{l}23 \text { Para evitar que se formen en mi mente imágenes de acontecimientos molestos, intento describir los aconteci- } \\
\text { mientos a través de un monólogo interno (cosas que me digo a mí mismo). }\end{array}$ & 2.20 & 1.08 & .57 \\
\hline
\end{tabular}




\begin{tabular}{|c|c|c|c|c|}
\hline No. & $\begin{array}{c}\text { Item } \\
\end{array}$ & $M$ & $S D$ & $r_{\text {corr }}$ \\
\hline & $\begin{array}{l}\text { Alejo de mi mente las imágenes mentales relacionadas con una situación amenazadora, intentando utilizar un } \\
\text { monólogo interno para describir la situación. }\end{array}$ & 2.23 & 1.05 & .65 \\
\hline & Pienso en las cosas que preocupan a otros en lugar de pensar en mis propias preocupaciones. & 2.05 & 1.08 & .43 \\
\hline
\end{tabular}

Note. CEC $=$ Cuestionario de Evitación Cognitiva $; r_{\text {corr }}=$ corrected item-total correlations.

Table 2. Original items of the CAQ (Sexton \& Dugas, 2008).

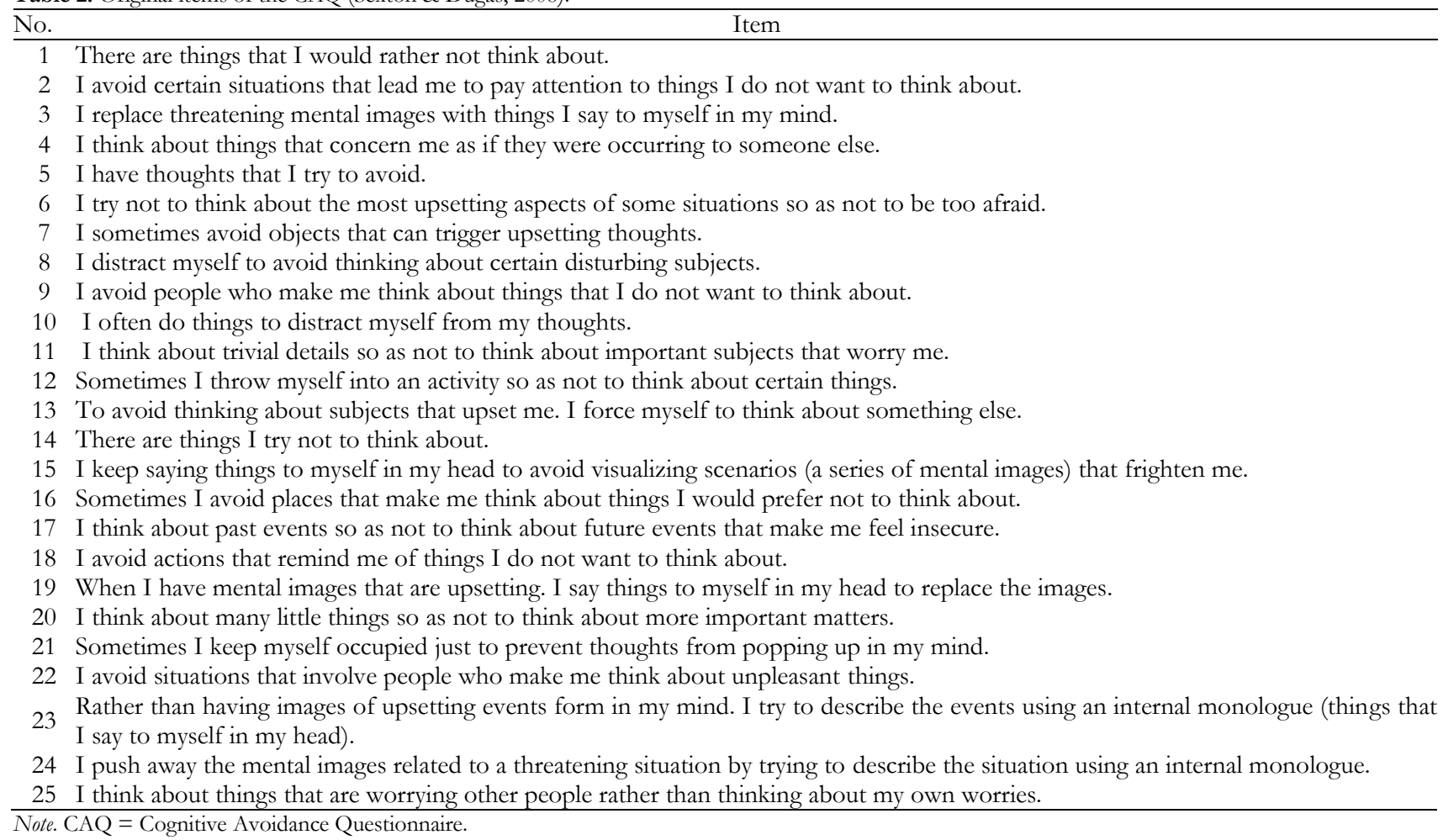

\section{Psychometric properties of the CEC}

\section{Confirmatory factor analysis}

As multivariate normality was not satisfied, the variables were ordinal, and the sample was large enough $(>200)$, the parameters were estimated using the asymptotic distributionfree method, namely, weighted least squares (Bollen, 1989; Kline, 1998, 2011). For the CFA, the variance of each factor was set at 1.0, and hence the loading of each CEC item could be freely estimated. The indicators loaded on only one factor and the errors of measurement were not included in the correlations in order to give greater accuracy to the validity of the indicator (Anderson \& Gerbing, 1988). As regards the estimators, the Comparative Fit Index (CFI), the Goodness of Fit Index (GFI), the Incremental Fit Index (IFI) and the Root Mean Square Error of Approximation (RMSEA) were used to evaluate the goodness of fit. The values of these statistics (CFI, GFI, and IFI) varied between 0 y 1 , where 1 indicates a perfect fit. Values above .90 suggest a satisfactory fit between the theoretical theories and empirical data, and values of .95 and above, an optimal fit (Hu \& Bentler, 1999). For RMSEA, values close to .05 are consid- ered optimal, although values up to .08 are acceptable (Byrne, 2001). With regard to $\chi^{2}$ (CMIN), although a nonsignificant value indicates the best fit, this statistic is influenced by sample size and thus some authors suggest the use of $\chi^{2} /$ degrees of freedom (CMIN/DF) as the most appropriate measure (Byrne, 2001). CMIN/DF $<3$ indicates an acceptable fit between the hypothetical model and sample data (Kline, 1998, 2011) and CMIN/DF $<5$ indicates a reasonable fit (Marsh \& Hocevar, 1985). Additionally, Akaike Information Criterion (AIC) is used to compare different models; lower scores indicate a better fitting model (Akaike, 1987). We conducted four models to examine the best fit between the theoretical structure and the empirical data. First, we replicated the five-factor structure of the CAQ (Sexton \& Dugas, 2008). Subsequently, the first model was opposed to other possible models to explore the existence of a general factor. Results of testing the four models are summarized in Table 3.

Model 1: Five-factor model. The model specification was based on the 25-item five-factor structure proposed both in the original French version (QEC), and the adaptation in English (CAQ). The fit indices are generally at or close to acceptable ranges indicating an acceptable fit of the five- 
factor model. The factor loadings were above .45. (Figure 1). All five CEC factors were robust interrelated $(>.50$; Cohen, 1988).

Model 2: Unidimensional model. A one-factor CFA was conducted, which assumed that the covariance among the 25 items of the CEC is due to a single common factor. However, a general factor showed a poor fit to the observed data. The factor loadings ranged between .24 and .74 .

Model 3: Five first-order factors and one second-order factor. In this model the intercorrelations among first-order factors form a system of interdependence that is itself important in measuring the construct. Each factor and second-order factor are necessary in capturing the nature of the construct domain. The second-order factor of the CEC exists but cannot be directly measured by indicator variables. It can only be inferred from the first-order factors, which in turn are measured by their respective indicator variables. A model was tested with five first-order factors (Thought Suppres- sion, Thought Substitution, Distraction, Avoidance of Threatening Stimuli, and Transformation of Images into Thoughts) and one second-order factor ( $\left.\mathrm{CEC}_{\text {total }}\right)$. The model showed a good fit. The factor loadings were above .53 . (Figure 2).

Model 4: Bi-factor model with a general factor and five group factors. Each individual item was specified to load directly on both its specific subscale (or factor) and on a general factor that is related to all items in a multidimensional measure. Unfortunately, the results for bi-factor model were not satisfactory.

In short, the model 1 and 3 were the best fit. As the statistics of both models were acceptable, we computed AIC. The AIC value for the five-factor model was 1076.72, and the AIC value for the five first-order factors and one second-order factor was 630.53. According to these results, the model 3 showed the best fit to the observed data.

Table 3. Confirmatory factor analyses results $(N=614)$.

\begin{tabular}{|c|c|c|c|c|c|c|c|}
\hline Model & CMIN (DF) & $\mathrm{CMIN} / \mathrm{DF}$ & CFI & IFI & GFI & RMSEA & AIC \\
\hline 1. Five-factor & $956.72 *$ & 3.61 & .91 & .91 & .90 & .06 & 1076.72 \\
\hline 2. One-factor & $942.29 *$ & 3.54 & .69 & 68 & .86 & .06 & 1060.29 \\
\hline 3. Five first-order factors and one second-order factor & 482.53* & 1.92 & .90 & 90 & .93 & .04 & 630.53 \\
\hline 4. Bi-factor model with a general factor and five group factors & $852.85^{*}$ & 3.48 & .72 & .73 & .87 & .06 & 1012.86 \\
\hline
\end{tabular}

Note. ${ }^{*} p<.001$.

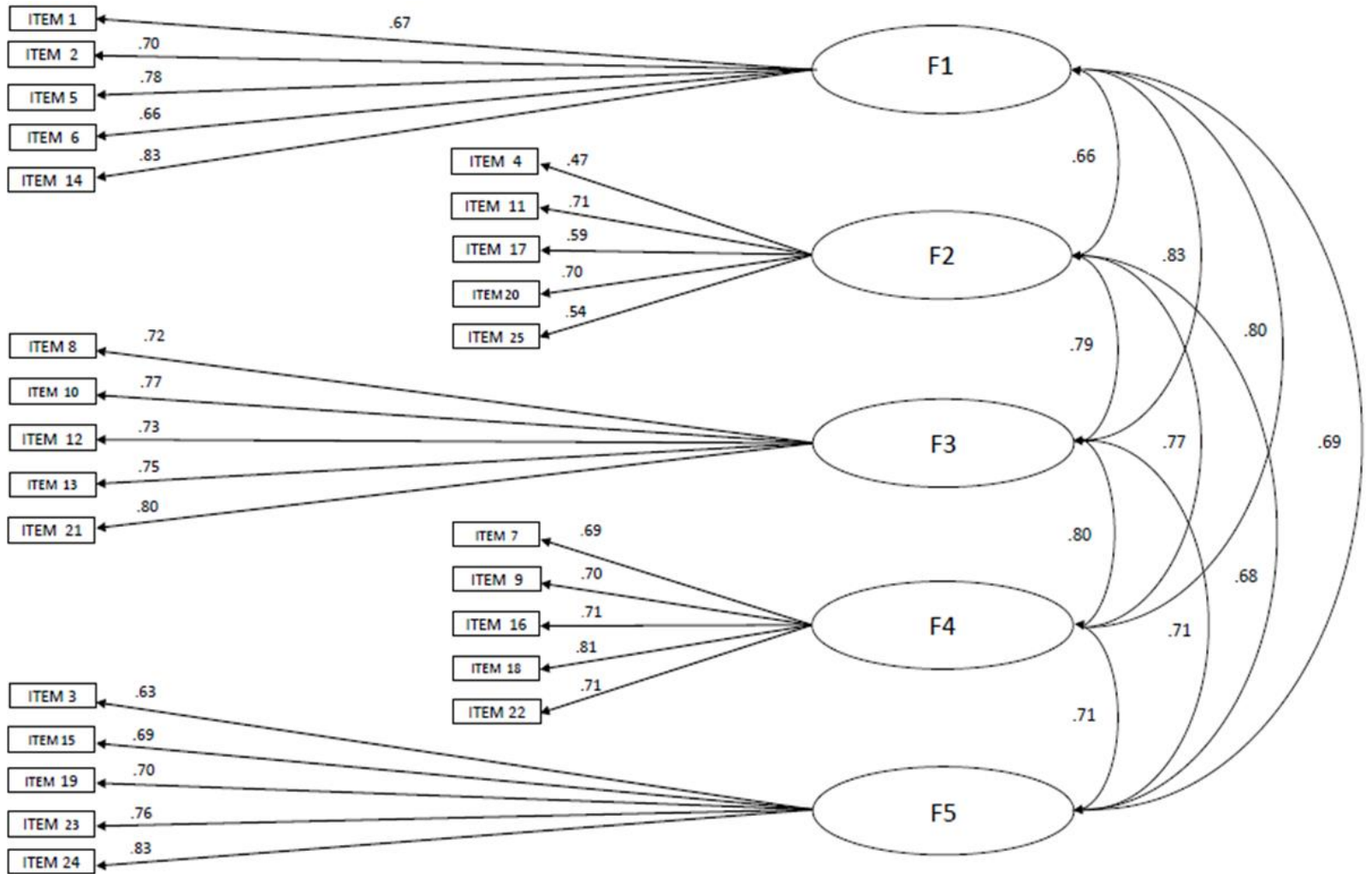

Figure 1. Factor loading of CFA: Five-factor model.

Note. F1 = Thought Suppression subscale; F2 = Thought Substitution subscale; F3 = Distraction subscale; F4 = Avoidance of Threatening Stimuli subscale; and F5 $=$ Transformation of Images into Thoughts subscale. All $p s<.001$. 


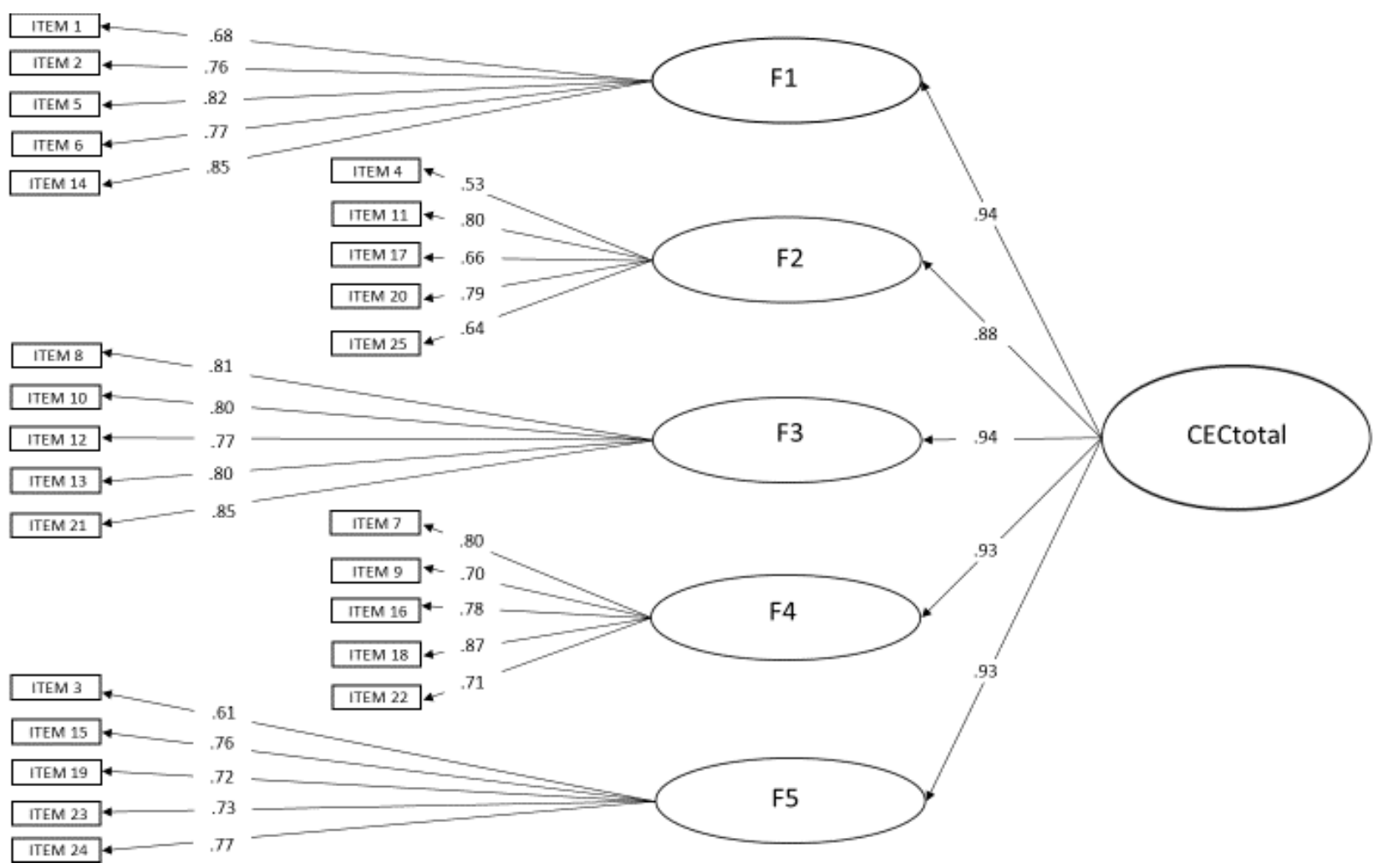

Figure 2. Factor loading of CFA: Second-factor model.

Note. F1 = Thought Suppression subscale; F2 = Thought Substitution subscale; F3 = Distraction subscale; F4 = Avoidance of Threatening Stimuli subscale; and F5 = Transformation of Images into Thoughts subscale; CEC total $_{1}$ Cuestionario de Evitación Cognitiva total.

$$
\text { All } p s<.001 \text {. }
$$

\section{Analysis of internal consistency}

Cronbach's alpha coefficient was used to analyze the internal consistency of the CEC and its five subscales. The internal consistency of the $\mathrm{CEC}_{\text {total }}$ was excellent $(a=.94)$. Cronbach's alpha for the five subscales were as follows:
Thought Suppression $(a=.85)$; Thought Substitution ( $a=$ .74); Distraction $(a=.87)$; Avoidance of Threatening Stimuli $(a=.85)$; and Transformation of Images into Thoughts $(a=$ .83). Additionally, Table 4 shows the correlations between empirical scores of the CEC subscales.

Table 4. Correlations between empirical scores of the CEC subscales and descriptive statistics.

1. Thought Suppression

2. Thought Substitution

3. Distraction subscale

4. Avoidance of Threatening Stimuli

5. Transformation of Images into Thoughts

6. $\mathrm{CEC}_{\text {total }}$

Mean

$S D$

\begin{tabular}{cccccc}
1 & 2 & 3 & 4 & 5 & 6 \\
- & & & & & \\
.51 & - & & & & \\
.71 & .60 & - & & & \\
.67 & .59 & .67 & - & & \\
.60 & .55 & .62 & .59 & - & \\
.85 & .76 & .88 & .85 & .81 & - \\
4.45 & 9.69 & 13.09 & 11.66 & 11.32 & 60.23 \\
4.54 & 3.63 & 4.64 & 4.57 & 4.21 & 18.02 \\
$5-25$ & $5-25$ & $5-25$ & $5-25$ & $5-25$ & $25-125$ \\
\hline
\end{tabular}

Note. CEC $=$ Cuestionario de Evitación Cognitiva.

All correlation indices were significant $p s<.01$.

\section{Construct validity of the CEC}

To analyze the convergent validity of the CEC, we analyzed its relation with other measures assessing theoretically similar constructs. Thus, we examined the correlations between the CEC and its five subscales and the measures of worry, rumination, thought suppression and cognitive avoidance in the CRI-A. For the discriminant validity, we used the cognitive approach strategies in the CRI-A (logical analysis and positive reappraisal). 


\section{Correlation with a measure of worry}

A moderate correlation was found between the $\mathrm{CEC}_{\text {total }}$ and the PSWQ $(r=.41, p<.01)$. The correlations of the five subscales of the CEC with the PSWQ were slightly lower than those with the total scale: thought suppression $(r=.35$, $p<.01)$; thought substitution $(r=.37, p<.01)$; distraction $(r$ $=.37, p<.01)$; avoidance of threatening stimuli $(r=.29, p<$ $.01)$; and transformation of images into thoughts $(r=.36, p$ $<.01)$.

\section{Correlation with a measure of rumination}

The measure of rumination considered was the Visual Analog Rumination Scale (VARS). It was found to be moderately and positively associated with the CEC $(r=.37, p$ $<.01)$. The analysis with the five CEC subscales yielded the following results: thought suppression $(r=.35, p<.01)$; thought substitution $(r=.25, p<.01)$; distraction $(r=.35$, $p$ $<.01)$; avoidance of threatening stimuli $(r=.31, p<.01)$; and transformation of images into thoughts $(r=.27, p<$ $.01)$. These correlations were either moderate or low, with the highest correlation being that with the $\mathrm{CEC}_{\text {total }}$.

\section{Correlation with a measure of thought suppression}

The WBSI yielded positive correlations ranging from moderate to high for both the total CEC $(r=.72, p<.01)$ and each of the five factors: thought suppression $(r=.67, p$ $<.01)$; thought suppression $(r=.47, p<.01)$; distraction $(r$ $=.71, p<.01)$; avoidance of threatening stimuli $(r=.56, p<$
$.01)$; and transformation of images into thoughts $(r=.58, p$ $<.01)$.

\section{Correlation with coping responses}

The $\mathrm{CECt}_{\text {otal }}$ was moderately correlated $(r=.48, p<.01)$ with the cognitive avoidance subscale from the CRI-A. This finding supports the convergent validity of the CEC with another cognitive avoidance scale. As regards discriminant validity, the correlations with the coping style strategies from the CRI-A were non-significant: logical analysis $(r=.17, p>$ $.05)$ and positive reappraisal $(r=.06, p>.05)$.

\section{Hierarchical regression}

To maximize knowledge of the load of each variable and study the incremental validity of the CEC with respect to worry, we conducted a hierarchical regression analysis, using the measure of worry (PSWQ) as dependent variable. At the first step, the cognitive avoidance scale from the CRI-A was entered, followed by the thought suppression variable measured by the WBSI, and, finally, the $\mathrm{CEC}_{\text {total. }}$. The results revealed that the thought suppression strategy was the strongest predictor of worry. However, the CEC was found to have very little weight in the prediction of this variable. The results, shown in Table 5, showed that at the second step the thought suppression measure was a significantly strong predictor of worry, with the predictive power of the cognitive avoidance scale from the CRI-A being lower, although the variable that least predicted worry was the $\mathrm{CEC}_{\text {total }}$.

Table 5. Hierarchical regression model $(\mathrm{N}=147)$.

\begin{tabular}{cccccccc}
\hline Dependent variable & Step & Predictor & $\Delta R^{2}$ & $\Delta F$ & $B$ & S.E. B & $\beta$ \\
\hline \multirow{2}{*}{ PSWQ } & 1 & CRI-A, EC & .029 & $3.91^{*}$ & -.16 & .28 & -.04 \\
& 2 & WBSI & .228 & $40.4^{* * *}$ & $.44^{* * *}$ & .09 & .49 \\
& 3 & CEC & .001 & .22 & .03 & .07 & .05 \\
\hline
\end{tabular}

Note. PSWQ = Penn State Worry Questionnaire; CRI-A, EC = Cognitive avoidance subscale, Coping Response Inventory for Adults; WBSI = White Bear Suppression Inventory; CEC = Cuestionario de Evitación Cognitiva. $* p<.05 ;{ }^{* * *} p<.001$.

\section{Discussion}

The CAQ assesses five forms of cognitive avoidance related to worry and GAD (e.g., Dugas et al., 2007; Robichaud, Dugas, \& Conway, 2003). The measure has not been studied in samples of individuals with anxiety, although the psychometric properties found in non-clinical samples have been adequate, and thus it can be considered a useful and reliable instrument to assess worry-related cognitive avoidance strategies. Consequently, the aim of the present study was to analyze the factor structure and the psychometric properties of the Spanish translation of the CAQ in a non-clinical sample.

According to previous researchs (Gosselin et al., 2002; Sexton \& Dugas 2008), the 25-item five-factor structure found in the present study showed an acceptable fit. Howev- er, when we opposed the five-factor model to other possible models to examine the existence of a general factor, we found that the second-order model (i.e., five first-order factors and one second-order factor) exhibited the best fit between the theoretical structure and the empirical data in the Spanish sample. Moreover, both the $\mathrm{CEC}_{\text {total }}$ scale and its subscales demonstrated good to excellent internal consistency. The CFA results yielded satisfactory goodness of fit for the CFI, IFI, GFI, CMIN/df and RMSEA. Nonetheless, it should be noted that our data did not follow a normal distribution and the indices were not wholly comparable with those of the reference study, as our structural equation modeling program was different from that used by Sexton and Dugas (2008). The factor loadings for each of the items on the CEQ were similar to those for the CAQ. The lower 
overall goodness of fit of the previous version was attributed to some of the items being loaded in more than one factor. However, as previously mentioned, the goodness of fit of our model was adequate.

To verify the convergent validity, we calculated the correlations between the CEC and the PSWQ worry measure, the two cognitive avoidance subscales from the CRI-A (cognitive avoidance) and the thought suppression factor from the WBSI. In addition, the decision to include the construct of rumination was motivated by the parallels established between this measure and worry, and the influence of cognitive avoidance in this process (Dickson et al., 2012). This triggered our interest in making a first approach to the relation between rumination and cognitive avoidance using the CEC, for which results were favorable given that they presented a significant correlation. This finding corroborates similar evidence provided by Moulds, Kandris, Starr, and Wong (2007), who conceptualized rumination as a cognitive avoidance strategy. Similar approaches have been developed, with a significant impact on clinical practice. For example, it has been suggested that rumination may serve to avoid painful aspects of loss, thereby hampering adjustment to bereavement (Eisma \& Stroebe, 2017), while Aldao et al. (2010) found that avoidance, rumination and suppression were among the strongest predictors of psychopathology symptoms. Finally, the discriminant validity of the CEC was demonstrated through its correlations with the measures of cognitive approach from the CRI-A (logical analysis and positive reappraisal). From the perspective of the classification of coping strategies, these results were as expected, given that logical analysis and positive reappraisal are considered to be approach styles, understood as cognitive or behavioral efforts focused on handling a stressor, and thus potentially opposed to avoidance strategies (Moos, 1993). Moreover, although cognitive avoidance strategies have been associated with psychopathology (e.g., Barajas et al., 2017: Hayes, 2016; Schäfer et al., 2017; Struijs et al., 2018), it should be taken into account that their use depends, among other elements, on the types of the stressors and individual and generational differences (e.g., Chen, Peng, Xu, \& O’Brain, 2018; Nieto et al., 2020).

With regard to the hierarchical regression analysis conducted to predict worry, the results were not as expected, given that CEC barely predicted the tendency toward worry. This was in contrast to the results of the study on the English version of the instrument in which CAQ was found to be a significant predictor of worry. However, coinciding with the study validating the English version, the measure of thought suppression, the WBSI, was the most robust predictor of worry.
This work has a number of limitations that should be considered. First, similarly to the English version, the study sample consisted entirely of participants without diagnosis of GAD or any other anxiety disorder. Thus, it would be necessary to analyze the factor structure and psychometric properties of the CEC in clinical samples to determine whether the instrument is equivalent in other populations. Second, the data on validity were only recorded in a sub-sample. A larger number of participants would be needed to corroborate these criteria and substantially enhance the quality of our research. Third, the study groups were not equivalent in size, given the majority were young adults. It would be useful to increase the number of middle-aged persons and older adults with the aim of conducting multi-group analyses to determine whether the CEC presents factor invariance across ages. Fourth, our results were not as expected with regard to the contribution of the CEC in explaining worry. Thus, more in-depth analysis of this issue would constitute an interesting future research line. Finally, as occurred with the validation of the $C A Q$, although a measure of worry was used to analyze the convergent validity of the questionnaire, its association with other processes related to worry was not analyzed, which was, however, done in the French version (Gosselin et al., 2002), nor was the CEC's relation to other anxiety disorder symptoms examined. It would be useful to include these additional measures in future studies.

To conclude, the CEC has been shown to be a useful instrument to assess the tendency to use cognitive avoidance as a strategy to deal with threatening intrusive thoughts. The present study identified five first-order factors and one second-order factor whose goodness-of-fit statistics were satisfactory. That is to say, this model showed that the responses to the measurement of cognitive avoidance could be explained by five first order factors (Thought Suppression, Thought Substitution, Distraction, Avoidance of Threatening Stimuli, and Transformation of Images into Thoughts) and there was one second-order factor $\left(\mathrm{CEC}_{\text {total }}\right)$ that underlies the five first-order factors. The total scale and subscales showed good to excellent internal consistency. Moreover, the questionnaire presented adequate convergent and discriminant validity. Thus, it can be considered the results reflect good preliminary data on the questionnaire. Our findings should serve as a starting point for subsequent, more exhaustive studies, which are needed in view of the implications for clinical practice of the use of cognitive avoidance strategies in anxiety disorders, and more particularly, in GAD.

Funding: This work was partially supported by Spanish Ministerio de Ciencia, Innovación y Universidades, Agencia Estatal de Investigación (AEI)/ European Regional Development Fund (FEDER, UE) under DPI2016-80894-R grant. 


\section{References}

Akaike, H. (1987). Factor analysis and AIC. Psychometrika, 52, 317-332. doi:10.1007/BF02294359

Aldao, A., Nolen-Hoeksema, S., \& Schweizer, S. (2010). Emotion-regulation strategies across psychopathology: A meta-analytic review. Clinical Psychology Review, 30, 217-237. doi:10.1016/j. cpr.2009.11.004

American Psychiatric Association. (2013). Diagnostic and statistical manual of mental disorders: DSM-5 (Fifth Edit). Washington, DC: American Psychiatric Association.

Anderson, J. C., \& Gerbing, D. W. (1988). Structural equation modeling in practice: A review and recommended two-step approach. Psychological Bulletin, 103, 411-423. doi: 10.1037/0033-2909.103.3.411

Arbuckle, J. L. (2014). AMOS-23. Chicago, IL: IBM SPSS.

Barajas, S., Garra, L., \& Ros, L. (2017). Avoidance in anxiety and depression: Adaptation of the Cognitive-Behavioral Avoidance Scale in a Spanish sample. The Spanish Journal of Psychology, 20, 1-11. doi: 10.1017/sjp.2017.16

Behar, E., DiMarco, I. D., Hekler, E. B., Mohlman, J., Staples, A. M., \& Dobrow, I. (2009). Current theoretical models of generalized anxiety disorder (GAD): Conceptual review and treatment implications. Journat of Anxiety Disorders, 23, 1011-1023. doi: 10.1016/j.janxdis.2009.07.006

Bollen, K. A. (1989). Structural equations with latent variables. New York, NY: Wiley.

Borkovec, T. D., Alcaine, O. M., \& Behar, E. (2004). Avoidance theory of worry and generalized anxiety disorder. Generalized anxiety disorder: Advances in research and practice (pp. 77-108). New York, NY: Guilford.

Borkovec, T. D., Robinson, E., Pruzinsky, T., \& DePree, J. A. (1983). Preliminary exploration of worry: Some characteristics and processes. Behaviour Research and Therapy, 21, 9-16. doi:10.1016/0005-7967(83)90121-

Bryne, B. M. (2001). Structural equation modeling with AMOS: Basic concepts, applications, and programming. Mahwah, NJ: Lawrence Erlbaum Associates.

Capobianco, L., Morris, J. A., \& Wells, A. (2018): Worry and rumination: do they prolong physiological and affective recovery from stress? Anxiety, Stress, \& Coping, 31, 291-303. doi:10.1080/10615806.2018.1438723

Chen, Y., Peng, Y., Xu, H., \& O’Brain, W. H. (2018). Age differences in stress and coping: Problem-focused strategies mediate the relationship between age and positive affect. The International Journal of Aging and Human Development, 86, 347-363. doi: 10.1177/0091415017720890

Cohen, J. (1988). Statistical power analysis for the behavioral sciences. (2nd ed) Hillsdale, NJ: Lawrence Erlbaum.

Dickson, K. S., Ciesla, J. A., \& Reilly, L. C. (2012). Rumination, worry, cognitive avoidance, and behavioral avoidance. Examination of temporal effects. Behaviour Therapy, 43, 629-640. doi: 10.1016/j.beth.2011.11.002

Dugas, M. J., Gagnon, F., Ladouceur, R., \& Freeston, H. (1998). Generalized anxiety disorder: A preliminary test of a conceptual model. Behaviour Research and Therapy, 36, 215-226. doi: 10.1016/S00057967(97)00070-3

Dugas, M. J., Savard, P., Gaudet, A., Turcotte, J., Laugesen, N., Robichaud, M., Francis, K., \& Koerner, N. (2007). Can the components of a cognitive model predict the severity of generalized anxiety disorder? Behavior Therapy, 38, 169-178. doi: 10.1016/j.beth.2006.07.002

Eifert, G. H., \& Forsyth, J. P. (2005). Acceptance and commitment therapy for anxiety disorders: A practitioner's treatment guide to using mindfulness, acceptance and values-based behavior change strategies. Oakland, CA: New Harbinger Publications.

Eisma, M., \& Stroebe, M. (2017). Rumination following bereavement: An overview. Bereavement Care, 36, 58-64. doi: 10.1080/02682621.2017.1349291

González, M., Avero, P., Rovella, A. T., \& Cubas, R. (2008). Structural validity and reliability of the Spanish version of the White Bear Suppression Inventory (WBSI) in a sample of the general Spanish population. Spanish Journal of Psychology, 11, 650-659.

Goodwin, H., Yiend, J., \& Hirsch, C. (2017). Generalized anxiety disorder worry and attention to threat: A systematic review. Clinical Psychology Review, 54, 107-122. doi: 10.1016/j.cpr.2017.03.006
Gosselin, P., Langlois, F., Freeston, M. H., Ladouceur, R., Dugas, M. J., \& Pelletier, O. (2002). Le Questionnaire d'e'vitement cognitif (QEC) De'veloppement et validation aupre`s d'adultes et d'adolescents [The CognitiveAvoidance Questionnaire (CAQ): Development and validation among adult and adolescent samples]. Journal de The 'rapie Comportementale et Cognitive, 12, 24-37.

Hambleton, R. K. (2005). Issues, designs and technical guidelines for adapting tests into multiple languages and cultures. In R. K. Hambleton, P. F. Merenda, \& S. D. Spielberger (Eds.), Adapting educational and psychological tests for cross-cultural assessment (pp. 3-38). Mahwah, NJ: Lawrence Erlbaum Associates.

Hayes, S. C. (2016). Acceptance and commitment therapy, relational frame theory, and the third wave of behavioral and cognitive therapies - republished article. Behavior Therapy, 47, 869-885. doi: 10.1016/j.beth.2016.11.006

Hayes, S. C., Wilson, K. G., Gifford, E. V., Follette, V. M., \& Strosahl, K. (1996). Experimental avoidance and behavioral disorders: a functional dimensional approach to diagnosis and treatment. Journal of Consulting and Clinical Psychology, 64, 1152-1168. doi:10.1037/0022-006X.64.6.1152

Hearn, C. S., Donovan, C. L., Spence, S. H., \& March, S. (2018). Do worry and its associated cognitive variables alter following CBT treatment in youth population with Social Anxiety Disorder? Results from a randomized controlled trial. Journal of Anxiety Disorders, 53, 46-57. doi:10.1016/j.janxdis.2017.11.005

Hirsch, C. R., Perman, G., Hayes, S., Eagleson, C., \& Mathews, A. (2015) Delineating the role of negative verbal thinking in promoting worry, perceived threat, and anxiety. Clinical Psychological Science, 3, 637-647. doi: $10.1177 / 2167702615577349$

Hu, L., \& Bentler, P. M. (1999). Cutoff criteria for fit indices in covariance structure analysis: Conventional criteria versus new alternatives. Struc tural Equation Modeling, 6, 1-55. doi:10.1080/10705519909540118

International Test Commission. (2016). The ITC Guidelines for translating and adapting tests (Second edition). Retrieved from: https://www.intestcom.org/

Kirchner, T., \& Forns, M. (2010). Spanish adaptation of Coping Responses Inventory-Adult. Madrid: TEA Ediciones.

Kline, R. B. (2011). Principles and practice of structural equation modeling ( $3^{\mathrm{a}} \mathrm{Ed}$.) New York: The Guilford Press.

Lobo, A., Saz, P., Marcos, G., \& Zaracemp, G. T. (2002). Spanish version of the Mini-Mental Cognitive Test (MEC). Madrid: TEA Ediciones.

Marsh, H. W., \& Hocevar, D. (1985). Application of confirmatory factor analysis to the study of self-concept: first-and higher order factor models and their invariance across groups. Psychological Bulletin, 97, 562-582. doi: $10.1037 / 0033-2909.97 .3 .562$

Matthews G., \& Wells A. (2004). Rumination, depression and metacognition: The S-REF Model. In C. Papageorgiou \& A. Wells (Eds.), Depressive rumination. Nature, theory and treatment (pp. 125-151). Chichester, UK: John Wiley \& Sons.

Meyer, T. J., Miller, M. L., Metzger, R. L., y Brokovec, T. D. (1990). Development and validation of the Penn State Wory Questionnaire. Behaviour Research and Therapy, 28, 487--495. doi: 10.1016/0005--7967(90)90135-6

Moos, R. (1993). Coping Responses Inventory: CRI Adult-Form. Odessa, Ukraine: Psychological Assessment Resources. Inc.

Moulds, M. L., Kandris, E., Starr, S., \& Wong, A. C. M. (2007). The relationship between rumination, avoidance and depression in a nonclinical sample. Behaviour Research and Therapy, 25, 251-261. doi: 10.1016/j.brat.2006.03.003

Newman, M. G., Llera, S. J., Erickson, T. M., Przeworski, A., \& Castonguay, L. G. (2013). Worry and Generalized Anxiety Disorder: A review and theoretical synthesis of evidence on nature, etiology, mechanisms, and treatment. Annual Review of Clinical Psychology, 9, 275-297. doi 10.1146/annurev-clinpsy-050212-185544

Nieto, M., Romero, D., Ros, L., Zabala, C., Martínez, M., Ricarte, J. J., Serrano, J. P., \& Latorre, J. M. (2020). Differences in coping strategies between young and older adults: The role of executive functions. The International Journal of Aging and Human Development. doi: $10.1177 / 0091415018822040$ 
Nolen-Hoeksema, S. (2000). The role of rumination in depressive disorders and mixed anxiety/depressive symptoms. Journal of Abnormal Psychology, 109, 504-511. doi:10.1037/0021-843X.109.3.504

Østefjells, T., Melle, I., Aminoff, S. R., Hellvin, T., Hagen, R., Lagerberg T. V., ... Røssberg, J. I. (2017). An exploration of metacognitive beliefs and thought control strategies in bipolar disorder. Comprehensive Psychiatry, 73, 84-92. doi: 10.1016/j.comppsych.2016.11.008

Raes, F., Hermans, D., Williams, J. M. G., Bijttebier, P., \& Eelen, P. (2007). A "Triple W" model of rumination on sadness: Why am I feeling sad, what's the meaning of my sadness, and wish I could stop thinking about my sadness (but I can't). Cognitive Therapy and Research, 32, 526541. doi:10.1007/s10608-007-9137-y

Raes, F., Hermans, D., Williams, J. M. G., \& Eelen, P. (2007). A sentence completion procedure as an alternative to the Autobiographical Memory Test for assessing overgeneral memory in non-clinical populations. Memory, 15, 495-507. doi: 10.1080/09658210701390982

Rousseeuw P. J., \& Leroy A. M. (1987). Robust regression and outlier detection. New York, NY: John Wiley \& Sons, Inc.

Ricarte, J. J., Aizpurúa, E., Ros, L., Latorre, J. M., \& Raes, F. (2018). Psychometric properties of the Spanish Short Depressive Rumination Scale in a nonclinical sample. The Spanish Journal of Psychology, 21, 1-10. doi: $10.1017 /$ sjp. 2018.35

Robichaud, M., Dugas, M. J., \& Conway, M. (2003). Gender differences in worry and associated cognitive-behavioral variables. Journal of Anxiety Disorders, 17, 501- 516. doi: 10.1016/S0887-6185(02)00237-2

Sagui-Henson, S. J. (2017). Cognitive Avoidance. Encyclopedia of Personality and Individual Differences, 1-3. doi:10.1007/978-3-319-28099-8_964-1

Sandín, B., Chorot, P., Valiente, R. M., \& Lostao, L. (2009). Validación española del cuestionario de preocupación PSWQ: estructura factorial y propiedades psicométricas [Spanish validation of the PSWQ concern questionnaire: factor structure and psychometric properties]. Revista de Psicopatologia y Psicología Clinica, 14, 107-122. doi: 10.5944/rppc.vol.14.num.2.2009.4070

Schäfer, J. Ö., Naumman, E., Holmes, E. A., Tuschen-Caffier, B., \& Samson, A. C. (2017). Emotion regulation strategies in depressive and anxiety symptoms in youth: A meta-analytic review. Journal of Youth and Adolescence, 46, 261-276. doi: 10.1007/s10964-016-0585-0

Segerstrom S. C., Tsao J. C. I., Alden L. E., \& Craske M. G. (2000). Worry and rumination: Repetitive thought as a concomitant and predictor of negative mood. Cognitive Therapy and Research, 24, 671-688. doi: 10.1023/A:1005587311498

Servatius, R. J. (2016). Avoidance: From basic science to psychopathology. Frontiers in Behavioral Neuroscience, 10, 15. doi: 10.3389/fnbeh.2016.00015

Sexton, K. A., \& Dugas, M. J. (2008). The Cognitive Avoidance Questionnaire: Validation of de English translation. Journal of Anxiety Disorders, 22, 335-370. doi: 10.1016/j.janxdis.2007.04.005

Struijs, S. Y., Lamers, F., Rinck, M., Roelofs, K., Spinhoven, P., \& Penninx, B.W. J. (2018). The predictive value of approach and avoidance tendencies on the onset and course of depression and anxiety disorders. Depression and Anxiety, 35, 551-559. doi: 10.1002/da.22760

Tabachnick, B. G., \& Fidell, L. S. (2001). Using multivariate statistics (4th ed.). Boston, MA: Allyn \& Bacon.

Watkins, E. D., \& Moulds, M. (2009). Thought Control Strategies, Thought Suppression, and Rumination in Depression. International Journal of Cognitive Therapy, 2, 235-251. doi:10.1521/ijct.2009.2.3.235

Wegner, D. M., \& Zanakos, S. (1994). Chronic thought suppression. Journal of Personality, 62, 615-640. doi: 10.1111/j.1467-6494. 1994.tb00311.x 